\title{
KONSTRUKSI INTEGRASI ILMU PENGETAHUAN DI UNIVERSITAS ISLAM RIAU
}

\author{
Musaddad Harahap \\ Fakultas Agama Islam Universitas Islam Riau \\ Jl. Kaharuddin Nasution, No. 113 Perhentian Marpoyan, Pekanbaru, 28284 \\ e-mail: musaddadharahap@fis.uir.ac.id
}

\begin{abstract}
Abstrak: Kajian ini berupaya menyingkap bagaimana konstruksi integrasi ilmu di Universitas Islam Riau (UIR). Dengan pendekatan metode grounded teory, kajian ini berupaya untuk menguatkan teori tentang integrasi ilmu dengan objek kajiannya di UIR. Data dalam kajian ini diambil dari studi lapangan dan observasi mendalam. Hasil kajian ini mengungkap bahwa konstruksi integrasi ilmu pengetahuan di UIR sejak berdirinya tahun 1962 merupakan cita-cita para pendirinya yang menghendaki kampus ini berasaskan Islam. Secara eksplisit, tema integrasi ilmu pengetahuan dapat dilihat dari rumusan tujuan UIR, yang turunannya telah melahirkan berbagai kebijakan seperti kurikulum pendidikan Islam, Lembaga Dakwah Islam Kampus, pembinaan ke-Islaman dosen dan pengawai, green campus, pembinaan baca tulis al-Qur'an untuk mahasiswa, kajian Islam rutin melalui pemberdayaan masjid, organisasi Islami mahasiswa di setiap fakultas, dan penanaman karakter kampus dengan konsep Cerdas, Empati, Religius, Ikhlas, dan Amanah (CERIA).
\end{abstract}

\begin{abstract}
The Construction of Science Integration in Islamic University of Riau. This study seeks to strengthen the theory of the integration of science with the object of study at Universita Islam Riau. The data was collected from field studies and in-depth observations. This study found that the construction of science integration at UIR since its establishment in 1962 was the ideals of its founders, so it was decided to be based on Islam. Explicitly the theme of science integration can be seen from the formulation of UIR objectives, that has given birth to various policies such as Islamic education curriculum, Campus Islamic Propagation Board, Islamic guidance for lecturers and employees, green campus, fostering reading and writing of the Koran for students, routine Islamic study circles, mosque empowerment, and internalization of campus character with the concepts of Smart, Empathy, Religiousity, Sincere, and Amanah (CERIA).
\end{abstract}

Kata Kunci: Islam, science, integration, Islamic University of Riau 


\section{Pendahuluan}

Secara bahasa integrasi dapat diartikan "penyatuan" yang antonimnya "pemisahan." Ilmu sendiri paling tidak dapat dilihat dari dua sudut pandang. Pertama dari bahasa Inggris yaitu science. Seiring perkembangan, kata ini pada akhirnya dipahami sebagai usaha untuk menjelaskan fenomena dunia fisik secara sistematis dengan cara observasi dan eksperimen. Kedua, bahasa Arab yaitu 'ilm dengan pengertian pengetahuan tentang segala hal sebagaimana mestinya. Dalam Islam, kata 'ilm merupakan salah satu sifat Allah SWT. yaitu 'Alîm (Maha Mengetahui). ${ }^{2}$ Jadi, Integrasi ilmu merupakan disiplin ilmu yang lahir pada abad ke-20 akibat adanya anggapan bahwa Barat menghembuskan kekacauan dalam memahami peran agama dalam kaitannya dengan perkembangan ilmu pengetahuan.

Sains modern yang identik dengan Barat secara fisik kelihatannya telah berhasil mengembangkan ilmu pengetahuan ke puncak yang cukup tinggi. Tetapi pada sisi metafisik peradaban Barat cukup memprihatinkan karena nilai-nilai dianggap tidak ada hubungannya dengan ilmu pengetahuan. Konflik antara ilmu dan agama pun semakin hari semakin tidak terbendung sehingga terbentuklah dua kelompok berseberangan yaitu pengikut optimisme ilmu pengetahuan dan agamawan murni. Secara umum, sejarah terjadinya fenomena kekacauan agama dan ilmu berawal dari pernyataan Nicolas Copernicus (1473-1543) bahwa pusat alam semesta adalah matahari, bukan bumi seperti yang dipahami selama 1800 tahun lamanya, sehingga para sejarawan menetapkan bahwa Nicolas adalah peletak awal perkembangan sains modern. Momentum revolusi ilmiah kemudian lahir dari pemikir asal Prancis, Rene Descartes (1596-1650) yang berpendapat bahwa dunia fisik hanya terdiri atas gerak partikel-partikel materi yang saling berinteraksi dan berbenturan antara satu dengan lainnya. ${ }^{3}$

Pemikiran Descartes pada akhirnya disempurnakan oleh Isaac Newton (1643-1727) sehingga lahir teori adanya kekuatan dahsyat mekanik dan dinamis (kalkulus) berdasarkan pada tiga prinsip yaitu setiap benda punya daya gravitasi terhadap benda lain, kekuatan daya di antara dua benda tergantung pada masanya, dan jarak antara dua benda membentuk kuadrat. Kemudian pemikiran Newton dikembangkan dan disempurkan Charles Darwin (1809-1882) dengan teori evolusi yaitu adanya hukum seleksi alam. Akibat dari kompleksitas pemikiran semacam ini pada akhirnya membawa konsep sains modern membuat jarak dan berkonfrontasi dengan agama. ${ }^{4}$

${ }^{1}$ Amril M., Epistemologi Integratif-Interkonektif Agama dan Sains (Jakarta: RajaGrafindo Persada, 2016), h. 2. Pembahasan tentang integrasi ilmu dalam bidang hukum lihat secara umum, Mhd. Syahnan , Hukum Islam dalam Bingkai Transdisipliner (Medan: Perdana Publishing, 2018), h. 62-80.

${ }^{2} \mathrm{Al}$ Rasyidin dan Ja'far, Filsafat Ilmu Dalam Tradisi Islam (Medan: Perdana Publishing, 2015), h. 54-56.

${ }^{3}$ Humaidi, Paradigma Sains Integratif Al-Farabi (Jakarta: Sadra Internaional Institute, 20015), h. 28.

${ }^{4} I b i d .$, h. 29-30. 
Kasus lain yang memicu gejolak antara ilmu dan agama adalah pernyataan Nietzsche bahwa Tuhan telah mati. Pengingkaran terhadap agama oleh para akademisi waktu itu mengalir deras sampai menemui jati dirinya. Paham sekuler dan liberalisme pun semakin diminati oleh generasi berikutnya. Bahkan sampai saat ini arus gelombang pemikiran itu masih terlihat jelas dalam kehidupan sehari-hari, bahkan dalam kehidupan kampus juga sulit untuk dinafikan. Fenomena ini sebetulnya sangat berbahaya bagi kemurnian hakikat ajaran Islam sebagai agama yang mengandung ajaran tauhid, seperti pernah diingatkan oleh Fazlur Rahman bahwa pendidikan Islam harus melakukan modernisasi tanpa harus meninggalkan ajaran dan tradisi para ulama di masa lalu. Paling tidak ada tiga hal yang harus dilakukan dalam memodernisasi pendidikan Islam ini. Pertama, meningkatkan kualitas para pendidik Muslim. Kedua, memberikan perhatian ekstra kepada peserta didik yang berbakat. Ketiga, pengadaan sarana dan prasarana 5

Selanjutnya, pemikiran-pemikiran sekuler dari tokoh-tokoh di atas pun pada akhirnya masuk ke Nusantara melalui imperialisme yang dilakukan oleh dunia Barat. Bibit sekuler ini terus menemukan momentumnya dengan lahirnya kebijakan-kebijakan yang mengarah kepada dikotomi ilmu di dalam pendidikan, bahkan terkesan pendidikan agama pada masa imperialisme dimarjinalkan karena dianggap sebagai ancaman terhadap eksistensi imperialis mereka dan bahkan dianggap penghambat perkembangan ilmu pengetahuan. Jadi, dominasi sains semasa kolonialisme semakin hari semakin memperlihatkan ketidak sejalanannya dengan agama, bahkan agama terkesan diingkari dan dilawan. ${ }^{6}$ Dampak perseteruan sains dan agama pada akhirnya dikenal dengan istilah dualisme dan dikotomi ilmu pengetahuan. Istilah ini merupakan konsep filsafat yang menggambarkan adanya dua subtansi, kemudian istilah ini diseret untuk menggambarkan perseteruan antara ilmu (science) dan agama (dîn) pasca Kolonial. Padahal dalam Islam ilmu pengetahuan idealnya hanya bersumber dari Allah SWT.

Kegelisahan pun muncul dalam dunia Islam yang kena dampak kolonialisme. Hal itu juga dirasakan di Indonesia. Efek dari kompleksnya persoalan di masa kolonial Belanda telah membawa Indonesia pada babak baru yaitu diskursus berkepanjangan dalam wacana sains dan agama. Pada akhir abad ke-19 pendidikan di Indonesia terdapat dualistik sistem. Di satu sisi pada masa itu Belanda memiliki pendidikan umum yang berupaya untuk memisahkan doktrin agama dari sekolah. Sedangkan di sisi lain penduduk Indonesia yang didominasi beragama Islam punya sistem pendidikan sendiriyaitu pendidikan agama murni tanpa ada pelajaran umum. ${ }^{7}$

${ }^{5}$ Muhammad Fahmi, "Pendidikan Islam Perspektif Fazlur Rahman," dalam Jurnal Pendidikan Agama Islam (Journal of Islamic Education Studies), Vol. 2, No. 2, 2014, h. 273-298.

${ }^{6}$ Muchlis Muhammad Hanafi, "Integrasi Ilmu dalam Perspektif al-Qur'an," dalam Suhuf Jurnal Pengkajian al-Qur'an dan Budaya, Vol. 3, No. 2, 2010, h. 175-191.

${ }^{7}$ Suaidi Asyari, "Incorporating Islamism Into Secular Education System: An Attempt of Gradual Islamization of the State and Society by an Indonesian Tarbiyah Movement in Jambi," dalam Journal of Indonesian Islam, Vol. 11, No. 1, 2017, h. 30. 
Kemudian istilah dualisme dan dikotomi pun mulai dipersoalkan oleh para pemikir Muslim sebab berdampak buruk bagi kehidupan umat Muslim terutama di Nusantara. Abdul Wahab ${ }^{8}$ menyebutkan pengaruh dualisme dan dikotomi ini bukan hanya pada tataran pemilahan, tetapi telah masuk pada wilayah pemisahan, misalnya ada pemisahan institusi dan operasional. Dalam bidang institusi adanya lembaga pendidikan umum dan pendidikan agama, sementara dalam bidang operasionalnya terjadinya pemisahan mata pelajaran umum dari mata pelajaran agama.

Di Indonesia sendiri puncak dari isu integrasi ilmu ini muncul ketika pemerintah membuka keran untuk mengkonversi STAIN ke IAIN, dan IAIN ke UIN. Paling tidak ada 7 alasan yang melatarbelakangi kenapa muncul gerakan konversi di PTAI yaitu politik, sosial-ideologis, kelembagaan, dunia kerja, keilmuan, pembangunan bangsa dan negara, kompetisi global, dan prinsip keterbukaan. ${ }^{9}$ Adapun di antara tokoh yang giat dan mendalami diskursus ini seperti Harun Nasution dengan gagasannya mendiseminasikan pemikiran rasionalisasi ilmu-ilmu ke-Islaman di Perguruan Tinggi Islam, A. Qodry Azizy dengan konsep ide humanisasi ilmu-ilmu ke-Islaman, M. Amin Abdullah dengan konsep integrasi-interkoneksi ilmu atau jaringan laba-laba ilmu, Imam Suprayogo dengan konsep pohon ilmu, Azyumardi Azra dengan gagasan reintegrasi ilmu, ${ }^{10} \mathrm{M}$. Nazir dari Universitas Islam Negeri (UIN) Sultan Syarif Kasim Riau dengan konsep paradigma Qurani dan tauhid. ${ }^{11}$

Walaupun tema integrasi ini mengalami pasang surut tetapi bagi setiap institusi terutama yang mengatasnamakan Islam punya beban moril untuk mendesain lembaga pendidikan yang mampu melahirkan ilmuwan dan agamawan, alim tentang teknologi sekaligus alim dalam bidang agama. Hal ini mengindikasikan bahwa al-Qur'an dan sunnah adalah sumber rujukan ketika berbicara tema-tema ilmu pengetahuan. ${ }^{12}$ Tema integrasi ilmu ini juga masih relevan untuk dikaji karena fakta menunjukkan bahwa di Indonesia masih terlihat adanya dua sistem pendidikan yaitu pendidikan yang dikelola Kementerian Agama dan pendidikan yang dikelola oleh Kemendikbud serta Kemenristek Dikti. Jadi, atas dasar ini pula pendapat Amin Abdullah pada tahun 2014 masih penting untuk direnungkan bahwa beliau melihat pada waktu itu pendidikan agama masih menerapkan paradigma konflik dan independen. Jika paradigma semacam itu masih dipertahankan tentu akan sangat mempengaruhi cara pandang terhadap agama, sosial, dan kultur. Dengan demikian

${ }^{8}$ Abdul Wahab, "Dualisme Pendidikan di Indonesia," dalam Lentera Pendidikan: Jurnal Ilmu Tarbiyah dan Keguruan, Vol. 16, No. 2, 2013, h. 220-229.

${ }^{9}$ Amiruddin Yahya, "Dinamika Lembaga Pendidikan Tinggi Islam di Indonesia," dalam MIQOT: Jurnal Ilmu-ilmu Keislaman, Vol. 41, No. 1, 2017, h. 98-117.

${ }^{10}$ Miftahuddin, "Integrasi Pengetahuan Umum dan keislaman di indonesia: Studi Integrasi Keilmuan di Universitas Islam Negeri di Indonesia," dalam Attarbiyah: Journal of Islamic Culture and Education, Vol. 1, No. 1, 2016, h. 89-118.

${ }^{11}$ Akbarizan, Integrasi Ilmu: Perbandingan antara UIN Suska Riau dan Universitas Ummu Al-Qur'an Makkah (Pekanbaru: Suska Press, 2014), h. 209.

${ }^{12}$ Ibid. 
pendidikan Islam masih memerlukan pola hubungan dan dialog yang integrasiinterkonektif. ${ }^{13}$ Adapun di Riau terdapat perguruan tinggi yang berasaskan Islam, selain UIN Sultan Syarif Kasim, salah satu lembaga pendidikan terbesar adalah Universitas Islam Riau (UIR). Karena itu, perlu dikaji apakah UIR memiliki konstruksi konsep integrasi ilmu dan Islam. Dengan metode grounded teory, kajian ini akan menelusuri data yang relevan dengan tema pembahasan. Kemudian teknik pengumpulan data yang digunakan adalah dokumentasi, wawancara dan observasi mendalam terkait dengan konstruksi integrasi ilmu pengetahuan seperti yang telah digaungkan pada abad 20 silam. Rumusan masalah dalam kajian adalah bagaimanakah konstruksi integrasi ilmu di Universitas Islam Riau yang notabenenya nomenklaturnya di Kementerian Riset dan Teknologi Pendidikan Tinggi Republik Indonesia (Kemenristek Dikti RI), bukan Direktorat Pendidikan Tinggi Keagamaan Islam Kementerian Agama Republik Indonesia (Diktis Kemenag RI). Selama pengumpulan data, dilakukan reduksi data, kemudian divalidasi, disajikan untuk dianalisis dan ditarik kesimpulan.

\section{Sejarah dan Tokoh Pendiri Universitas Islam Riau}

Riau merupakan daerah religius yang berkebudayaan budaya Melayu. Bila dilihat dari akar sejarahnya Riau merupakan penggabungan dari beberapa kerajaan Melayu yang pernah berkuasa di masa lalu. Pada masa itu ada Kerajaan Indragiri (1658-1838), Kerajaan Siak Sri Indrapura (1723-1858), Kerajaan Pelalawan (1530-1879), Kerajaan RiauLingga (1824-1913) dan beberapa kerajaan kecil lainnya, seperti Tambusai, Rantau Binuang Sakti, Rambah, Kampar dan Kandis. Awalnya ibukota Riau adalah Tanjung Pinang (1958), namun pada tahun 1959 ibukota Riau pindah ke Pekanbaru. ${ }^{14}$ Jadi perpindahan ibukota Riau ke Pekanbaru menjadi babak baru untuk membangun Riau ke arah yang lebih modern dengan tetap mempertahankan nilai-nilai religius yang berkebudayaan budaya Melayu.

Sejauh ini Riau sudah berusia 61 tahun dan telah dipimpin gubernur sebanyak 17 orang. ${ }^{15}$ Selama 61 tahun itu daerah ini telah mengalami kemajuan yang sangat pesat, baik dalam bidang sosial, ekonomi, politik, dan terutama di bidang pendidikan. Terkait dengan pendidikan, Riau memiliki salah satu lembaga pendidikan yang usianya hanya selisih 5 tahun $^{16}$ dengan usia Riau itu sendiri, yaitu Universitas Islam Riau (UIR).

Universitas Islam Riau merupakan salah satu lembaga pendidikan tertua dan terbesar

\footnotetext{
${ }^{13} \mathrm{M}$. Amin Abdullah, "Religion, Science and Culture An Integrated, Interconnected Paradigm of Science," dalam Al-Jami'ah: Journal of Islamic Studies, Vol. 52, No. 1, 2014, h. 175-176.

${ }^{14}$ Pemerintah Provinsi Riau, "Sejarah Terbentuknya Riau," dalam https://www.riau.go.id/ home/content/61/data-umum, 06 Agustus 2018.

${ }^{15}$ Ibid.

${ }^{16}$ Riau yang dimaksud adalah Riau pasca terjadinya peristiwa sejarah perpindahan ibukota dari Tanjung Pinang ke Pekanbaru berdasarkan keputusan Menteri Dalam Negeri No. Desember /I/44-25 pada tanggal 20 Januari 1959. Ibid.
} 
yang ada di provinsi Riau. Universitas ini berdiri beberapa waktu sebelum berdirinya Universitas Riau (25 September 1962) ${ }^{17}$, Universitas Islam Negeri Sultan Syarif Kasim Riau (1970) ${ }^{18}$, dan Universitas Lancang Kuning (1982). Universitas Islam Riau tepatnya berdiri pada hari Selasa, 4 September 1962 berdasarkan akta notaris tahun 1962 dan diresmikan oleh Menteri Agama Republik Indonesia (sekarang Kementerian Agama RI) yang dituangkan dalam piagam yang ditanda tangani pada hari Kamis, 18 April 1963. Kemudian akta notaris pendirian Universitas Islam Riau yang pertama diperbaiki pada tahun 1972 dengan akta nomor 15 tanggal 30 September oleh Notaris Syawal Sutan. Pada hakikatnya Universitas Islam Riau adalah perguruan tinggi swasta yang lahir dari rahim yayasan yang didirikan oleh masyarakat dengan membentuk badan penyelenggara. Yayasan tersebut dinamai Yayasan Lembaga Pendidikan Islam Riau atau sering disingkat dengan YLPI Riau. ${ }^{19}$ Selain Universitas Islam Riau, YLPI juga membina beberapa lembaga pendidikan mulai dari TK, SD, SMP, dan SMA yang tersebar di berapa wilayah di provinsi Riau. Namun lembagalembaga pendidikan yang ada tersebut lebih banyak berada di Kota Pekanbaru. ${ }^{20}$ Adapun moto YLPI Riau adalah “...berbuat baiklah (kepada orang lain) sebagaimana Allah telah berbuat baik kepadamu... (Q.S. al-Qashshash/28: 77).

Sebelumnya YLPI merupakan hasil pengembangan dari Lembaga Pendidikan Islam (LPI) yang berdiri pada tahun 1951. Empat tahun setelah LPI terbentuk, ditingkatkanlah status LPI menjadi YLPI pada tahun 1955. Setelah itu pengurus YLPI menyadari bahwa sebuah yayasan haruslah berbadan hukum, dan atas dasar pemikiran visioner itu para pengurus berupaya untuk membuat akte pendirian yayasan yang dihadapan Bapak Abdul Moin, Bupati Kampar pada waktu itu, maka lahirlah akte yayasan pada tanggal 30 Maret 1957 dengan nomor 10/1957. Tokoh-tokoh yang terlibat langsung dalam pengurusan akte tersebut dan sekaligus penghadap dalam pengurusannya adalah Buya Zaini Kunin, Soeman Hs, dan Abdul Rasyid. Dengan demikian dalam akte nomor 10/1957 ini YLPI telah menjelma sebagai yayasan yang berbadan hukum dan sekaligus menjadi yayasan yang memiliki struktur kepengurusan untuk pertama kalinya. Adapun Buya Zaini Kunin

${ }^{17}$ Universitas Riau berdiri pada tanggal 25 September 1962 beberapa waktu setelah berdirinya UIR tertanggal 4 September 1962. Jadi hubungan dua perguruan tinggi ini sampai sekarang sangat baik. Lihat Universitas Riau, dalam http://unri.ac.id/sejarah/," 04 Agustus 2018.

${ }^{18}$ UIN Suska adalah satu lembaga PTAIN yang berhasil melakukan konversi dari IAIN menuju UIN tepatnya pada tahun 2015. Awalnya UIN Suska disebut dengan IAIN Susqa berasal dari beberapa Fakultas dari Perguruan Tinggi Agama Islam Swasta yang kemudian dinegerikan, yaitu Fakultas Tarbiyah Universitas Islam Riau di Pekanbaru, Fakultas Syariah Universitas Islam Riau di Tembilahan, dan Fakultas Ushuluddin Mesjid Agung An-Nur Pekanbaru. Seperti halnya UIR dan UR, UIN Suska Riau juga memiliki hubungan yang sangat baik sampai sekarang. UIN Suska Riau, "Sejarah Singkat Universitas," dalam https://uin-suska.ac.id/profil/sejarah-ringkasuniversitas/, 06 Agustus 2018.

${ }^{19}$ Statuta YLPI Tahun 2013 Nomor: 001/YLPI-Riau/I/2013, h. 4-5.

${ }^{20}$ YLPI, Sejarah Singkat, Visi dan Misi Serta Keadaan YLPI Riau Saat Ini (Pekanbaru: YLPI, 2017), h. 3-4. 
telah ditetapkan dalam kepengurusan itu sebagai Ketua Umum untuk membawa YLPI ke arah yang dicita-citakan sebelumnya. ${ }^{21}$

Merujuk kepada cikal bakal lahirnya YLPI tersebut, dapatlah dipahami bahwa pendirian UIR hakikatnya banyak dipengaruhi pemikiran-pemikiran Buya Zaini Kunin yang ditopang oleh semangat pembaharuan dari tokoh-tokoh semasanya. Karena pada waktu itu Riau dari segi pendidikan, terutama pendidikan Islam jauh tertinggal dibandingkan daerah-daerah lain. Kebutuhan untuk menyiapkan tenaga-tenaga ahli yang berpendidikan juga menjadi faktor pendukung sehingga pendirian perguruan tinggi semakin dirasakan keperluannya, apalagi pada waktu itu perguruan tinggi di Riau belum ada. Sebagai efek dari semangat mulia itu lahirlah lembaga-lembaga pendidikan yang berlandaskan Islam. Tokoh-tokoh yang terlibat dalam pencanangan pendirian UIR adalah Dt. Wan Abdurrahman, Soeman Hs, H.A. Malik, H. Bakri Sulaiman, A. Kadir Abbas, SH., dan H.A. Hamid Sulaiman. ${ }^{22}$ Patut juga dicatat bahwa keberhasilan pendirian UIR maupun beberapa perguruan tinggi lainnya seperti Universitas Riau dan UIN Sultan Syarif Kasim benarbenar didukung oleh pemerintah daerah pada waktu itu yang dipimpin oleh Gubernur Tingkat 1 Riau Brigjend H. Kaharuddin Nasution, bahkan beliau pernah terlibat langsung memimpin UIR selama tiga priode yaitu dari tahun $1962-1967 .{ }^{23}$

Kemudian, pada awalnya Universitas Islam Riau hanya memiliki satu fakultas, yaitu Fakultas Agama yang terdiri dari dua jurusan, yaitu Jurusan Hukum dan Tarbiyah. Fakultas Agama ini dipimpin pertama kali oleh Dekan A. Kadir Abbas, SH. Kampus pertama ini terletak di Jl. Prof. Mohd. Yamin, SH Pekanbaru dengan dua lantai. Tercatat beberapa tokoh yang pernah terlibat langsung dalam proses pembelajaran pada kampus pertama ini. Di Jurusan Tarbiyah ada H. Bakri Sulaiman, H.A. Hami Sulaiman, Abd. Rahim Manafi, H. dan Nasaruddin Thaha. Untuk Jurusan Hukum sendiri ada A. Kadir Abbas, SH., Nazar Said, SH, dan Sofyan Mukhtar, SH. Mereka semua termasuk generasi awal yang telah meletakkan dasar pemikiran dan perjuangan dalam sejarah perjalanan Universitas Islam Riau berikutnya. ${ }^{24}$

Setelah Universitas Islam Riau mencapai usia 23 tahun (1962-1983), dilakukan pengembangan yang sangat signifikan dengan membeli lahan seluas 65 Ha yang terletak di Jln. Kaharuddin Nasution No. 113, Pekanbaru, 28284, Riau. Pembangungan fisik pertama pun dilakukan pada tahun yang sama yaitu dengan mendirikan gedung Fakultas

${ }^{21} I b i d .$, h. 1-2. Naskah ini merupakah makalah yang diberikan kepada peserta pembinaan keagamaan oleh Universitas Islam Riau pada tahun 2017. Kegiatan pembinaan keagamaan ini diselenggarakan oleh UIR melalui LDIK dan setiap dosen, tenaga pendidik, dan karyawan di UIR wajib untuk mengikuti kegiatan tersebut.

${ }^{22}$ Detri Karya, Buku Pedoman Akademik UIR Unggul dan Terkemuka di Asia Tenggara 2020 (Pekanbaru: UIR, 2014), h. 5-6.

${ }^{23} I b i d .$, h. 7 dan 9.

${ }^{24}$ Ibid., h. 6 . 
Pertanian, dimana sebelumnya Pakultas Pertanian ini telah berdiri pada tahun 1977. Seiring dengan perkembangan waktu, kampus baru ini kemudian menjadi pusat administrasi Universitas Islam Riau secara total terhitung tahun 1990/1991 sampai sekarang (2018) menggantikan kampus lama di Jln. Prof. Mohd. Yamin, SH Pekanbaru. Sementara kampus pertama dialihkan menjadi SMP Islam YLPI sampai sekarang (2019). ${ }^{25}$

Sebagai lembaga pendidikan tinggi, saat ini UIR telah berusia 57 tahun (2019). Bila dibandingkan dengan kehidupan umat manusia, 56 tahun merupakan usia yang sudah matang dengan segudang pengalaman. Seperti diuraikan sebelumnya pada masa-masa awal berdirinya UIR hanya memiliki satu fakultas dengan dua jurusan. Tetapi sekarang UIR (2019) telah memiliki 9 fakultas dengan 42 Program Studi dan 1 Program Pascasarjana. Fakultas-fakultas yang ada di lingkungan UIR lebih didominasi oleh fakultas-fakultas umum bila dibandingkan dengan fakultas keagamaan. Dari 9 fakultas tersebut, terdapat satu fakultas agama yang disebut dengan Fakultas Agama Islam. Berikut diuraikan sepak terjang masingmasing fakultas dan program pascasarjana secara kronologis sesuai dengan tahun berdirinya.

- Fakultas Hukum berdiri tahun 1963.

- Fakultas Agama Islam berdiri tahun 1963.

- Fakultas Tehnik berdiri tahun 1964.

- Fakultas Pertanian berdiri tahun 1977.

- Fakultas Ekonomi berdiri tahun 1982.

- Fakultas Keguruan dan Ilmu Pendidikan berdiri tahun 1982.

- Fakultas Ilmu Sosial Ilmu Politik berdiri tahun 1982.

- Fakultas Psikologi berdiri tahun 2005.

- Fakultas Ilmu Komunikasi berdiri tahun 2009.

- Program Pascasarjana berdiri tahun 2003. ${ }^{26}$

\section{Kurikulum Universitas Islam Riau}

Dalam Statuta UIR tahun 2013, kurikulum diposisikan sebagai pedoman penyelenggaraan pendidikan untuk mewujudkan alumni yang mampu menguasai pengetahuan, keterampilan, dan sikap, sesuai dengan tujuan asasi program pendidikan yang dilaksanakan. Dalam penerapannya kurikulum di UIR tetap mengacu kepada kurikulum nasional dan lokal melalui kurikuler, kokurikuler dan ekstrakurikuler. Kurikulum di UIR sangat dinamis dan responsif terhadap perubahan sehingga kurikulumnya dicanangkan harus dapat menyesuaikan diri dengan kebutuhan dan perkembangan dunia usaha, pemerintah, dan masyarakat. Bukti kepekaan UIR dengan perubahan, dapat dilihat dalam Statuta bahwa di sana telah dinyatakan agar masing-masing program studi dapat merumuskan dan meninjau kembali

${ }^{25}$ Ibid., h. 13-15.

${ }^{26}$ YLPI, Sejarah Singkat, Visi dan Misi, h. 8-10. 
kurikulumnya secara berkala agar kurikulum yang ada tidak stagnan dan monoton. Kemudian perlu dipahami bahwa UIR sesungguhnya memberikan kebebasan kepada program studi untuk menetapkan kurikulumnya dengan tetap memperhatikan statuta UIR dan YLPI dan perundang-undangan yang berlaku. Mekanisme penetapan kurikulum ini bersifat usulan dari program studi melalui pimpinan fakultas dan selanjutnya akan disahkan oleh Rektor melalui SK Rektor yang kemudian akan dikirimkan kembali ke masing-masing fakultas. ${ }^{27}$

Selanjutnya secara garis besar kurikulum di UIR dibagi menjadi tiga komponen kurikulum utama yaitu, Kurikulum Universitas, Fakultas, dan Program Studi. Berkenaan dengan kurikulum universitas, universitas tetap memposisikan kurikulum wajib nasional sebagai acuan, dan ditambah dengan kurikulum pendukung sesuai dengan visi dan visi UIR. Kurikulum wajib nasional yang dimuat dalam kurikulum UIR adalah Pendidikan Kewarganegaraan, Pendidikan Pancasila, Bahasa Indonesia, dan Bahasa Inggris. Rumpun kurikulum ini berlaku untuk semua program studi di lingkungan UIR. Sebagai tambahan dari kurikulum wajib nasional, UIR memiliki kurikulum yang termanisfestasikan menjadi mata kuliah yaitu Pendidikan Agama Islam, Al-Islam I tentang Ibadah dan Mu'amalah, Al-Islam II tentang Akhlak, dan Al-Islam III tentang Islam dan Keilmuan. ${ }^{28}$ Bahkan di beberapa program studi ada juga mata kuliah dengan penyebutan Tamaddun Melayu.

Dari berbagai kurikulum UIR tersebut terlihat dengan jelas bahwa UIR telah berupaya untuk menjadikan Islam sebagai landasan dalam pengembangan setiap disiplin ilmu di lingkungan UIR, terutama fakultas-fakultas umum yang notabenenya lebih didominasi mahasiswa-mahasiswa yang bukan berasal dari pondok atau madrasah. Hal ini sudah menjadi kewajiban bagi UIR untuk mentransformasikan nilai-nilai keislaman terhadap mahasiswanya karena lembaga ini berada dalam dekapan YLPI dan lembaganya pun tetap mencantumkan nama besar Islam. Kalau tidak, nama besar Islam yang melekat dalam lembaga ini akan menjadi beban berat (dilema). Jadi, UIR sejauh ini telah dan akan terus berpaya untuk melahirkan generasi masa depan yang terlatih dengan pendidikan masa kini dengan tetap memperhatikan nilai-nilai keislaman. Konsep semacam ini benar-benar sejalan seperti pernah diungkapkan oleh Abdul Hafiz ${ }^{29}$ yaitu pendidikan yang seimbang sangat penting, yaitu pendidikan yang menekankan pada aspek insan baik dari segi intelek, rohani, emosi, maupun jasmaninya.

${ }^{27}$ Statuta Universitas Islam Riau, h. 14.

${ }^{28}$ Surat Keputusan Rektor Universitas Islam Riau Nomor 1142/UIR/KPTS/2016 Tentang Penetapan Rencana Pembelajaran Semester Mata Kuliah Agama Islam Universitas Islam Riau, Pekanbaru, 21 Desember 2016.

${ }^{29}$ Abdul Hafiz Mat Tuah. "Pendekatan Falsafah Sains al-Qur'an Dalam Kurikulum Pendidikan Kebangsaan," dalam Jurnal Ushuluddin, Vol. 23, No. 2, 2017, h. 143-154. 


\section{Integrasi Ilmu Pengetahuan di Universitas Islam Riau}

Integrasi ilmu merupakan gagasan yang lahir pada abad ke-20, sebagai bentuk respons dari kegelisahan yang terjadi pada masa itu. Perkembangan Barat yang semakin kompleks seolah-olah tidak terbendung, sehingga mau tidak mau memaksa umat Muslim mencari formulasi agar Islam itu tidak menjadi momok bagi perkembangan Barat tersebut. Berawal dari lahirnya pemikiran-pemikiran, temuan-temuan dunia Barat menjadi pertanda dimulainya kehidupan baru umat manusia. Sepintas memang perkembangan ilmu dan teknologi sangat membantu kehidupan manusia, tetapi pada sisi lain perkembangan ilmu dan teknologi tersebut sering menjadi malatapetaka dalam kehidupan manusia itu sendiri. Terperangkapnya pemikiran-pemikiran Barat ke dalam dilema yang berkepanjangan, oleh pemikir Muslim disebut sebagai ekses dari ketidak pedulian terhadap nilai-nilai ilahiah.

Sementara Islam sendiri pada awalnya telah mengembangkan pendidikan yang syarat dengan nilai-nilai Ilahiah. Namun semenjak daerah Muslim dijajah oleh bangsa Barat, maka secara perlahan virus pemikiran-pemikiran sekuler telah merasuk ke dalam pikiran para umat Islam. Untuk mempercepat misi Barat di daerah jajahan maka domain pendidikan agama dan sistem pendidikan akademik pun dipisahkan, satu-satu tujuan yang ingin mereka peroleh adalah untuk memisahkan ilmu pengetahuan umat Islam dari dimensi Ilahiah, sehingga mereka hidup secara sekuler seperti halnya gaya hidup orang Barat (westernisasi). ${ }^{30} \mathrm{Jadi}$ hal ini tentu harus menjadi perhatian umat Islam, sehingga mau tidak mau dalam mengembangkan sistem pendidikan haruslah sesuai dengan falsafah agama Islam itu sendiri. Pendidikan Islam harus punya kerangka yang tepat untuk membantu generasi muda, sehingga mereka memiliki kompetensi untuk menghadapi dan memecahkan berbagai persoalan dalam kehidupan global di masa yang akan datang. ${ }^{31}$ Selain dari pada itu umat Islam juga harus aktif mengambil peran untuk menjaga lembaga-lembaga pendidikan yang ada agar jangan sampai anak-anak Muslim yang masuk dalam lembaga itu tidak mendapat pendidikan agama yang standar.

Universitas Islam Riau seperti disebutkan sebelumnya lahir dari rahim Islam itu sendiri. Walaupun UIR belum secara jelas merumuskan konsep integrasi ilmu sebagai ciri khas layaknya beberapa institusi Islam ternama di Indonesia, tetapi UIR dalam sistem pengelolaannya secara tidak langsung telah membuat kerangka integrasi yang bertujuan untuk menopang percepatan lahirnya peradaban Islam khususnya di Riau.

Dalam Statuta UIR terbitan tahun 2013 dengan tegas disebutkan bahwa visi UIR adalah "Menjadikan Universitas Islam Riau yang Unggul dan Terkemuka di Asia Tenggara Pada Tahun 2020". Sedangkan misi yang diemban UIR adalah berupaya untuk menyelenggarakan pendidikan

${ }^{30}$ Azam Othman, et al., "Islamic Integrated Education System Model in the Malay Archipelago: Implications for Educational Leadership," dalam Intellectual Discourse, Vol. 25, No. 1, 2017, h. 203-204.

${ }^{31}$ Ibid. 
dan pengajaran, penelitian, pengabdian kepada masyarakat, dan Dakwah Islam yang berkualitas untuk mendukung pembangunan nasional dan internasional, menumbuhkembangkan kehidupan akademik yang sehat serta membangun pengembangan Ilmu Pengetahuan, Tekhnologi dan Humaniora yang berwawasan ke-Islaman dan ke-Indonesiaan mewujudkan kampus madani. ${ }^{32}$ Ada tiga hal yang patut dicatat dalam rumusan ini. Pertama, UIR adalah sosok lembaga pendidikan tinggi yang sangat visioner dan memiliki progres demi kemajuan umat dan bangsa, baik secara nasional maupun internasional. Kedua, UIR berupaya memadukan dakwah Islam dengan undang-undang nomor 12 tahun 2012 tentang pendidikan tinggi pasal 1 ayat 9 yaitu Tri Dharma Perguruan Tinggi. ${ }^{33}$ Ketiga, pengembangan sains di UIR digagas dan dikembangkan berbasis ke-Islaman dan ke-Indonesian.

Dalam statuta UIR tahun 2013 kalimat integrasi memang tidak ditulis secara tegas. Namun di sana dapat dipahami bahwa Islam dalam aktivitas kampus benar-benar menjadi perhatian khusus. Istilah integrasi ini kemudian muncul secara jelas dalam rumusan misi pimpinan terpilih (2017) pada poin keempat dari enam poin. Pertama, menyelenggarakan pendidikan dan pengajaran yang berkualitas. Kedua, menyelenggarakan penelitian yang kreatif dan inovatif untuk memperkaya khazanah ilmu pengetahuan dan menciptakan inovasi baru. Ketiga, menyelenggarakan pengabdian kepada masyarakat sebagai tanggungjawab sosial kemasyarakatan. Keempat, menyelenggarakan dakwah Islamiah dan pengintegrasian keislaman dan ilmu pengetahuan. Kelima, menyelenggarakan manajemen universitas yang bersih dan transparan. Keenam, membangun kemitraan yang saling menguntungkan dengan perguruan tinggi, industri, masyarakat dan pemerintah, baik lokal, nasional maupun internasional. ${ }^{34}$

Dalam poin keempat tersebut terlihat kalimatnya menggunakan kalimat aktif. Ini menunjukkan bahwa UIR adalah kampus yang berupaya untuk melaksanakan pendidikan dan pengajaran, penelitian, pengabdian, manajemen, dan kolaborasinya bersandar pada nilai-nilai ke-Islaman sehingga Islam dan ilmu pengetahuan berjalan seiring tanpa menafikan satu sama lain, bahkan penghayatan terhadap ajaran Islam diharapkan mampu melahirkan formulasi dan inovasi baru keilmuan untuk mendukung pembangunan nasional maupun internasional. ${ }^{35}$ Keterbukaan ini tampaknya lahir dari warisan cita-cita pemikiran para founding fathers YLPI dan UIR yang berharap munculnya pendidikan berbasis Islam di Riau untuk melahirkan generasi profesional yang tetap bertauhid kepada Allah SWT. Hal ini patut diapresiasi bahwa generasi UIR masih menjalankan fungsinya sesuai nawa cita para pendirinya walaupun perkembangan zaman semakin kompleks dan kompetitif.

${ }^{32}$ Statuta Universitas Islam Riau, h. 11.

${ }^{33}$ Tridharma adalah kewajiban Perguruan Tinggi untuk menyelenggarakan Pendidikan, penelitian, dan pengabdian kepada masyarakat. Tertuang dalam Undang-Undang Republik Indonesia Nomor 12 Tahun 2012 Tentang Pendidikan Tinggi, (Jakarta: 2012), h. 14.

${ }^{34}$ Universitas Islam Riau, "Visi, Misi dan Tujuan UIR," dalam https://uir.ac.id/visi-misi, 14 Oktober 2018.

${ }^{35}$ Statuta Universitas Islam Riau, h. 11. 
Pada tataran teoretis UIR termasuk salah satu dari banyak universitas di Indonesia yang berupaya menerapkan gagasan integrasi Islam dan sains. Memang harus disadari bahwa implementasi integrasi nilai dan sains bukanlah pekerjaan mudah, seperti digambarkan oleh Amril dalam bukunya bahwa konsep dan perbincangan integrasi di Indonesia memang mengalami pasang surut dan praktiknya pun dilakukan secara masif. Kebuntuan implementasi integrasi nilai dan sains ini paling tidak dilatarbelakangi dua hal yaitu belum maksimalnya kesiapan sumber daya manusia dan iklim akademik yang cenderung kaku, pada akhirnya berdampak terhadap percepatan pencapaian integrasi itu sendiri. ${ }^{36} \mathrm{Di}$ UIR sendiri tema integrasi ini telah terimplementasikan ke berbagai aktivitas sebagai upaya percepatan untuk mewujudkan visi dan misi UIR yang sudah ditetapkan sebelumnya. Indikatorindikator itu dapat dirinci sebagai berikut:

\section{Formulasi Kurikulum Pendidikan Agama Islam}

Dinamika perkembangan kurikulum pendidikan Islam perlu mendapat perhatian ekstra agar setiap rumusan kebijakan sesuai dengan hakikat tujuan pendidikan. Diketahui bahwa pendidikan Islam di Indonesia masih jauh dari harapan karena masih banyak output yang belum memiliki kompetensi atau kepribadian yang diharapkan. ${ }^{37}$ Kelihatannya atas kenyataan inilah sehingga materi pendidikan agama pada hakikatnya tertuang dalam amanah undang-undang Republik Indonesia Nomor 12 Tahun 2012 tentang Pendidikan Tinggi. Pendidikan agama termasuk salah satu mata kuliah wajib yang harus diselenggarakan oleh setiap institusi pendidikan tinggi di seluruh wilayah kesatuan Republik Indonesia. ${ }^{38}$ Dalam penyelenggaraannya setiap perguruan tinggi diberi kebebasan oleh pemerintah untuk mengembangkannya dengan mengacu kepada standar nasional pendidikan tinggi. Berhubung UIR adalah lembaga pendidikan tinggi yang berasaskan Islam, pendidikan agama sebagaimana diamanahkan oleh undang-undang tersebut dikembangkan sesuai prinsip dasar Islam itu sendiri.

Pengembangan materi pendidikan agama di UIR dirumuskan dalam bentuk Surat Keputusan Rektor Nomor 1142/UIR/KPTS tahun 2016 tentang Penetapan Rencana Pembelajaran Semester (RPS) Mata Kuliah Agama Islam. Dalam surat keputusan ini ditegaskan bahwa setiap dosen wajib mempedomaninya dan berlaku untuk semua program studi kecuali program studi di bawah Fakultas Agama Islam. ${ }^{39}$ Pendidikan Agama Islam di UIR meliputi

\footnotetext{
${ }^{36}$ Amril M., Epistemologi Integratif-Interkonektif Agama dan Sains, h. 1.

${ }^{37}$ Yunus Mustaqim, "Pengembangan Konsepsi Kurikulum Dalam Pendidikan islam," dalam Edukasia: Jurnal Penelitian Pendidikan Islam, Vol. 9 No. 1, 2014, h. 1-24.

${ }^{38}$ Undang-Undang Republik Indonesia Nomor 12 Tahun 2012, h. 28.

${ }^{39}$ Fakultas agama Islam secara nomenklatur berada di bawah garis koordinasi direktorat pendidikan tinggi keagamaan Islam melalui Kopertais wilayah XII Riau-Kepri, berbeda dengan fakultas lainnya yang bernomenklatur ke Kemenristekdikti melalui LLDIKTI wilayah X Sumatera Barat, Riau, Jambi, dan Kepulauan Riau (dulu Kopertis wilayah X). Namun pada bulan Oktober
} 
empat rumpun pembahasan, masing-masing 2 SKS sehingga totalnya 8 SKS, dan mata kuliah ini disajikan dalam empat semester, dimulai dari semester satu sampai empat.

Rumpun Pendidikan Agama pertama adalah Pendidikan Agama Islam. Dalam mata kuliah ini UIR berupaya untuk menjadikan mahasiswa menjadi orang-orang yang paham tentang bagaimana korelasi manusia dan agama, kesadaran dan kedewasaan beragama, karakteristik agama Islam, sumber pokok ajaran Islam, ruang lingkup ajaran Islam, akidah Islam, dan bagaimana penyimpangan akidah.

Rumpun Pendidikan Agama kedua adalah Al-Islam I (Ibadah dan Mu'amalah) yang berisikan materi tentang syariat dan fikih, fikih thaharah, fikih salat, fikih zakat, fikih puasa, fikih haji dan umrah, fikih muamalah, fikih jual beli dan riba, fikih munakahat, farâ'id, dan jinayah.

Rumpun Pendidikan Agama ketiga adalah Al-Islam II (Akhlak). Dalam mata kuliah ini disajikan materi tentang definisi akhlak, urgensi dan kedudukan akhlak dalam Islam, relevansi iman-Islam-ihsan, klasifikasi dan karakteristik akhlak, akhlak kepada Allah, akhlak terhadap manusia, akhlak terhadap alam dan lingkungan, pembentukan karakter Islam, internalisasi nilai-nilai akhlak dalam kehidupan, konsep dan implementasi CERIA ${ }^{40}$ UIR, akhlak terpuji dan tercela.

Sedangkan rumpun mata kuliah Pendidikan Agama Islam yang keempat adalah Al-Islam III (Islam dan Keilmuan). Materi yang disajikan dalam mata kuliah ini meliputi karakteristik ajaran Islam, paham sekulerisme, konsep akal dan wahyu dalam Islam, kedudukan ilmu dalam Islam, metode pengembangan Ilmu, konstruksi keilmuan dalam Islam dan Barat, isu-isu aktual seperti demokrasi dan HAM, pluralisme, fundamentalisme, radikalisme, terorisme, Islam dan kepemimpinan, dan konsep dasar Islam keilmuan fakultas.

Bila dilihat formulasi kurikulum pendidikan agama Islam yang disajikan di UIR tampaknya cukup komprehensif dan tersusun secara hierarki. Secara umum memang Islam hanya berkaitan dengan tiga persoalan yaitu Akidah, Syariah, dan Akhlak. Ketiga ini memiliki fungsi masing-masing tetapi satu sama lain saling berkaitan dan tidak dapat dipisahkan. Kelihatannya UIR benar-benar sadar tentang hal itu, sehingga dalam kurikulumnya ketiga persoalan itu disusun rapi secara prosedural. Adapun menempatkan akidah sebagai materi pertama merupakan pilihan yang tepat dan sangat sesuai dengan prinsip dasar Islam yaitu tauhid sebagai pengenalan terhadap Allah SWT., dengan pengenalan yang baik ini akan berdampak kepada berbagai aktivitas kehidupan lainnya, termasuk pengembangan

2018 dinyatakan fakultas agama Islam dan seluruh prodi di dalamnya dileburkan ke LLDIKTI wilayah X. Disebabkan perbedaan nomenklatur tersebut maka mata kuliah agama Islam seperti tertuang dalam SK Rektor tersebut tidak menjadi kewajiban bagi prodi di bawah fakultas agama Islam. Dengan meleburnya fakultas agama Islam ke LLDIKTI bisa jadi kebijakannya berubah, hanya saja sekarang masih dalam masa transisi.

${ }^{40}$ CERIA merupakan singkatan dari Cerdas, Empati, Religius, Ikhlas, dan Amanah. 
ilmu pengetahuan. Osman Bakar menyebutkan bahwa orang Muslim idealnya meletakkan tauhid sebagai sumber ilmiahnya. Bahkan secara teoretis kesadaran ilmiah tidak seharusnya bertentangan dengan kesadaran religius, karena aktivitas keilmuan merupakan bagian yang terpadu dengan ke-Esaan Tuhan itu sendiri. ${ }^{41}$ Ini artinya orang Muslim tidak boleh malu dengan agamanya, tetapi mereka harus bangga menampilkan agama sebagai sumber inspirasi dalam melakukan berbagai hal, baik pendidikan dan pengajaran, penelitian, dan pengabdian maupun dakwah Islamiyah.

Sementara syariah dan akhlak secara hierarki lahir sebagai konsekuensi terhadap keyakinan terhadap Allah SWT. sehingga pada akhirnya manusia mampu meraih derajat seperti disebut dalam al-Qur'an, Khalîfah fi al-Ardh. Manusia sebagai khalifah banyak disinggung dalam al-Qur'an, seperti dalam surah al-Fâthir/35: 39, "Dia-lah yang menjadikan kamu khalifah-khalifah di muka bumi...". Kata khalifah sendiri bermakna menggantikan orang lain, baik karena ia tidak hadir, karena meninggal, karena lemah atau tua, maupun tujuan memuliakan orang yang terdahulu. ${ }^{42}$ Pendapat lain menyebutkan, selain makna pengganti, kata khalîfah berarti sebagai pemimpin, manusia juga adalah penyambung titah Tuhan di muka bumi, atau manusia juga diperkenankan untuk memakmurkan bumi. ${ }^{43}$ Dengan demikian posisi manusia di muka bumi memiliki fungsi yang cukup strategis. Pada tataran inilah manusia dituntut untuk mampu mengembangkan segala potensinya agar fungsinya sebagai khalifah dapat terimplementasikan dengan baik. Dengan pemanfaatan potensi ini akan melahirkan berbagai ilmu pengetahuan, kreasi, inovasi dan sebagainya, tetapi tetap pada lingkup ke-Islaman. Oleh karena itu, UIR sebagai lembaga pendidikan Islam tetap harus memperhatikan hal ini. Secara normatif UIR memang telah meletakkan dasar-dasar itu, namun dalam tataran aktualnya UIR harus tetap berupaya mempertahankannya sekaligus meningkatkannya agar outcome yang tiap tahunnya mencapai 3000-an mampu bersaing dan menempatkan diri dengan tepat.

\section{Pembinaan Ke-Islaman Civitas Akademika UIR}

Universitas Islam Riau termasuk institusi yang cukup peduli dalam pengembangan diri dosen, pegawai dan karyawannya. Selain peningkatan akademik dengan memposkan dana untuk pendidikan dan pengajaran, penelitian, dan pengabdian, seluruh civitas akademik di UIR juga mendapat pos dana untuk peningkatan ke-Islaman melalui Lembaga Dakwah Islam Kampus (LDIK).

LDIK UIR digagas untuk bergerak di bidang dakwah. Posisi LDIK sendiri adalah sebagai

\footnotetext{
${ }^{41}$ Osman Bakar, Tauhid dan Sains Esai-Esai Tentang Sejarah dan Filsafat Sains Islam (Bandung: Pustaka Hidayah, 1995), h. 1.

${ }^{42}$ Al-Raghib Al-Ashfahani, Al-Mufradat fi Gharib al-Qur'an, terj. Ahmad Zaini Dahlan, Jilid 1 (Depok: Pustaka Khazanah Fawa'id, 2017), h. 680.

${ }^{43} \mathrm{Al}$ Rasyidin, Falsafah Pendidikan Islami, Membangun Kerangka Ontologi, Epistimologi, dan Aksiologi Praktik Pendidikan (Bandung: Citapustaka Media Perintis, 2012), h. 27.
} 
lembaga yang sejajar dengan lembaga lain seperti Lembaga Penjaminan Mutu (LPM) dan Lembaga Penelitian dan Pengabdian Kepada Masyarakat (LPPM). LDIK secara kelembagaan berdiri pada tahun 2009 dengan dasar Statuta Universitas Islam Riau tahun 2013 dan Surat Keputusan Rektor Universitas Islam Riau Nomor: 297/UIR/KPTS/2013 tentang Pengangkatan Ketua dan Sekretaris LDIK UIR. ${ }^{44}$

Lahirnya LDIK tidak dapat dipisahkan dari visi misi YLPI dan visi misi UIR yang secara nyata telah menarasikan Islam dan dakwah Islam sebagai semboyan. Untuk menopang implementasi dari ide suci tersebut tentu perlu lembaga yang fokus melakukan kajian, kegiatan, dan menyusun berbagai agenda ke-Islaman baik untuk internal maupun eksternal. Terkait dengan internal, selain membina mahasiswa agar menjadi orang yang taat beragama sekaligus mampu berdakwah di tengah-tengah masyarakat, LDIK juga bertanggung jawab untuk memastikan dosennya paham dan taat beragama.

UIR memang serius dalam menjadikan Islam sebagai asasnya sehingga ditetapkan bahwa seluruh dosen, pengawai, dan karyawan wajib mengikuti pembinaan ke-Islaman ini. Dalam praktiknya, kegiatan ini dilakukan secara bertahap kepada masing-masing dosen, pengawai, dan karyawan hanya diperkenankan ikut sekali setelah dinyatakan bergabung dengan UIR. Tindak lanjut dari program ini adalah kegiatan-kegiatan keagamaan yang digagas YLPI dan UIR. Kemudian setiap UIR melakukan rekruitmen baik dosen, pegawai, dan karyawan baru, mereka juga akan mendapatkan kegiatan dan pengalaman yang sama.

Adapun materi yang diberikan dalam kegiatan pembinaan ke-Islam cukup variatif. Materi-materi itu misalnya tentang ketauhidan, ke-YLPI-an, akhlak, unsur-unsur dakwah di kampus, peran dakwah dalam perguruan tinggi, dan peran wanita dalam berdakwah. Narasumber yang memberikan materi ini terdiri dari para sesepuh YLPI dan UIR dan juga melibatkan para ulama, pakar, dan tokoh dari luar kampus. Kegiatan ke-Islaman ini memakan waktu selama dua sampai tiga hari. Bagi peserta yang dinyatakan lulus, UIR akan memberikan sertifikat dan menjadi syarat untuk mengurus beberapa hal terkait dengan status kepegawaian di YLPI Riau.

Selain itu pembinaan ke-Islaman kepada mahasiswa juga dilakukan dengan berbagai kegiatan dan kebijakan. Misalnya dibentuknya Unit Kegiatan Mahasiswa Islam (UKMI) di bawah kontrol Wakil Rektor III. UKMI ini bergerak dalam ke-Islaman dan memiliki unit di setiap fakultas. Kemudian UIR juga bertanggung jawab untuk memastikan setiap mahasiswa Muslim wajib mampu membaca al-Qur'an dan ini menjadi syarat untuk ujian skripsi. Dalam Surat Keputusan Rektor Nomor 296/UIR/KPTS/2018 tentang Tim Seleksi Mentor Bimbingan Baca al-Qur'an dijelaskan bahwa kemampuan membaca al-Qur'an

${ }^{44}$ Lembaga Dakwah Islam Kampus, "Latar Belakang Lembaga Dakwah Islam Kampus," dalam http://ldik.uir.ac.id/wb/pg/article/program/detail/1109/, 14 Oktober 2018. 
adalah kewajiban mahasiswa. Pelaksana program ini adalah dosen-dosen dan mahasiswa yang sudah diseleksi dan diberikan Surat Keterangan (SK) oleh Rektor UIR. Jadi, programprogram unggulan ini merupakan upaya UIR untuk menciptakan kampus yang Islami serta aktivitasnya pun selalu bersandar kepada ajaran Islam.

\section{Kajian Rutin Kampus}

Untuk menyemarakkan nilai-nilai Islam, usaha UIR tidak terhenti hanya pada kurikulum maupun pembinaan dosen, pegawai dan karyawan. Berbagai strategi pun dilakukan untuk menjaga kontiniutas pemahaman, penghayatan, dan pengamalan terhadap agama Islam. Kajian rutin ini berpusat di masjid UIR ${ }^{45}$ yang terdiri dari tiga bentuk. Pertama, kajian rutin qabla dan ba'da salat Zuhur dan Asar. Pembicara dalam kajian ini adalah dosen-dosen atau pegawai yang memiliki potensi berdakwah. Materi yang disajikan dalam kajian telah diatur oleh pengurus masjid. Kedua, kajian yang dilakukan sebulan sekali yang akan melibatkan para pimpinan baik dari YLPI, Rektorat, maupun fakultas di lingkungan Universitas Islam Riau. Ketiga, kajian tabligh akbar yang dilaksanakan pada hari-hari besar Islam, seperti bulan maulid Nabi Muhammad SAW., Israk Mikraj, Sya’ban, musim haji, 'Asyura', menyambut bulan puasa Ramadan, menyambut tahun baru Hijriyah, halal bi halal lepas hari raya Idul Fitri, dan halal bi halal lepas hari raya Idul Adha. Pembicara dalam model ketiga ini dengan mengundang para ulama atau dai dari luar kampus baik dari Riau maupun dari luar propinsi Riau.

Sasaran dari kajian rutin ini adalah seluruh keluarga besar UIR, mulai dari pimpinan, dosen, pegawai, karyawan, sampai kepada mahasiswa. Penanggung jawab kegiatan kajian rutin ini adalah ketua masjid dan dipertanggungjawabkan langsung kepada pimpinan universitas. Jadi, dengan menerapkan pola seperti ini diharapkan mampu menjaga dan membangkitkan semangat civitas akademika untuk mengantarkan UIR unggul 2020 dengan landasan nilai-nilai ke-Islaman. Bila Islam sudah menjadi bagian dari kehidupan kampus, maka konsep dakwah Islamiyah dan konsep integrasi Islam dengan sains akan lebih besar kemungkinan terwujud.

Meskipun banyak orang yang pesimis dengan konsep integrasi Islam dengan sains dan konsep dakwah Islamiyah, UIR tidak akan terpedaya, malah UIR tetap istikamah untuk membentuk iklim tersebut. Terbentuknya iklim kampus yang penuh warna ke-Islaman mau tidak mau berkonsekuensi pada lahirnya tradisi akademis Islami di dalam kehidupan kampus. Jika nilai-nilai Islam telah menjadi landasan dalam mengembangkan ilmu

${ }^{45}$ Masjid ini bernama masjid Munawwarah. Masjid ini juga menjadi salah satu lokus penting terutama pembinaan mahasiswa dengan berbagai kegiatan-kegiatan Islami, seperti diskusi, kajian hadits, tafsir, fikih, tahfidz, dan sebagainya. Kemudian pengelola masjid munawarrah juga bersinergi dengan LDIK dan pengelola asrama UIR dalam membina mahasiswa supaya mereka tumbuh dengan kemulian Islam itu sendiri. 
pengetahuan tentu penyalahgunaan terhadap teori, konsep, dan pemanfaatannya dapat terminimalisir. Jadi, menjadi insan akademis tidak harus melupakan agama, atau sebaliknya untuk menjadi orang yang taat beragama tidak harus mengabaikan ilmu pengetahuan, apalagi menjadi fundamentalis agama dalam pengertian negatif. Garadian menyebutkan bahwa prinsipnya menjadi fundamentalis terhadap agama tidak salah, tetapi jangan sampai membentuk perilaku eksklusif, intoleran, apalagi mengedepankan kekerasan. ${ }^{46}$

\section{Pengembangan Pendidikan Karakter}

Dalam Statua UIR, tujuan berdirinya UIR adalah menemukan, mengembangkan, dan menyebarluaskan ilmu Islami. Subjek yang berperan untuk mensukseskan cita-cita itu adalah seluruh civitas akademika terutama dosen dan mahasiswa. UIR punya cita-cita agar para SDM-nya dan juga alumninya kelak menjadi ilmuwan yang profesional dan berkepribadian Islami. Adapun indikator-indikator yang diharapkan dimiliki setiap SDM di UIR adalah cerdas, empati, religius, bersusila, cakap, ikhlas, dan amanah, serta bertanggungjawab untuk mengembangkan ilmu pengetahuan. ${ }^{47}$

Memiliki karakter cerdas, empati, religius, bersusila, cakap, ikhlas, dan amanah, serta bertanggungjawab merupakan ciri-ciri pribadi yang unggul. Untuk itu UIR yang memiliki visi unggul 2020 idealnya harus mampu menginternalisasikan nilai-nilai itu ke dalam setiap komponen yang ada. Untuk mempermudah pencapaian nilai-nilai karakter ini UIR memilih sebuah slogan CERIA yaitu Cerdas, Empati, Religius, Ikhlas, dan Amanah. Lahirnya slogan CERIA merupakan bentuk komitmen UIR terhadap pendahulunya yang bercitacita untuk membentuk manusia yang berakhlak mulia lewat lembaga pendidikan. Konsep ini jika dikaitkan dengan pendapat Mollah ${ }^{48}$ maka akan muncul istilah interaksi edukatif. Dalam interaksi edukatif ini sebagaimana terdapat dalam al-Qur'an kisah tentang kisah Nabi Khidir dan Nabi Musa, kisah Nabi Ibrahim dan Nabi Ismail, kisah Luqman dan anaknya maka paling tidak ada lima hal interaksi edukatif. Pertama, tujuan pendidikan yaitu humanisasi, insân kâmil dan akhlak mulia. Kedua, pendidik yaitu bijaksana, penuh kasih sayang, demokratis, mengenal murid dan memahami kejiwaannya, berpengetahuan luas, memahami materi, sabar dan ikhlas. Ketiga, anak didik yaitu patuh, tabah, sabar, cita-cita yang kuat serta tidak putus asa dan bersungguh-sungguh, sopan santun, rendah hati dan hormat pada guru. Keempat, materi yaitu akidah, syariah dan akhlak. Kelima, metode yaitu dialogis, uswah hasanah, demokratis, dan mau'izhah.

${ }^{46}$ Endi Aulia Garadian, "Para Wali Nyentrik: Rekontekstualisasi Islamisasi di Tanah Jawa, Menantang Fundamentalisme Islam," dalam Studia Islamika, Vol. 26, No. 2, 2019, h. 391.

${ }^{47}$ Statuta Universitas Islam Riau, h. 11.

${ }^{48}$ Moch. Kalam Mollah, "Konsep Interaksi Edukatif Dalam Pendidikan Islam Dalam Perspektif al-Qur'an," dalam Jurnal Pendidikan Agama Islam (Journal of Islamic Education Studies), Vol. 3, No. 2, 2015, h. 235-256. 
Jadi, interaksi edukatif ini sangat tepat diberlakukan dalam dunia akademis. Walaupun fungsi kampus identik dengan pengembangan ilmu pengetahuan tetapi lembaga pendidikan Islam tidak boleh lepas dari upaya pembinaan akhlak. Menjunjung tinggi nilai-nilai akhlak adalah kewajiban semua civitas akademika. Oleh karena itu, konsep CERIA merupakan model pengembangan karakter di UIR. Istilah CERIA terdiri dari lima variabel dan masing-masing variabel memiliki dimensi yang harus dikembangkan dalam kehidupan kampus UIR. ${ }^{49}$ Pertama, cerdas memiliki beberapa dimensi yaitu rasa ingin tahu, gemar membaca, mandiri, kreatif, dan kerja keras. Kedua, empati dengan dimensi memiliki sikap toleransi, peduli sosial, menghargai prestasi, persahabatan, komunikatif, kolaboratif, dan cinta damai. Ketiga, religius yaitu taat beragama, toleran terhadap pemeluk agama lain, hidup rukun dengan pemeluk agama lain, dan jujur. Keempat, ikhlas terdiri dari sabar dan demokratis. Kelima, amanah meliputi tanggung jawab, cinta tanah air, disiplin, semangat kebangsaan, dan peduli lingkungan. ${ }^{50}$

Formulasi CERIA sebetulnya tidak dapat dipisahkan dengan hasil refleksi UIR terhadap ajaran Islam. Istilah CERIA sengaja digalakkan agar iman dan takwa yang bersemayam dalam diri manusia mampu tumbuh dan berkembang bersama gejala-gejala positif sebagaimana tertuang dalam dimensi-dimensi CERIA itu. ${ }^{51}$ Selanjutnya setelah perencanaan pendidikan karakter berhasil dirumuskan maka UIR berkomitmen untuk memberikan fasilitas agar CERIA ini benar-benar dapat dilaksanakan dan dikendalikan dalam kegiatan pendidikanpengajaran, penelitian, pengabdian, dan dakwah Islamiyah. Hal ini merupakan bagian upaya integrasi yang dicanangkan UIR. Konsep CERIA bagi UIR sebuah keharusan yang dapat mewarnai catur dharma, budaya organisasi, kegiatan mahasiswa, dan kegiatan keseharian $^{52}$ sehingga terciptalah kampus Darussalam yaitu Universitas Islam Riau yang madani. Pada akhirnya alumninya akan menjadi tenaga-tenaga ahli profesional yang memiliki wawasan bernuansa Islam dan tetap mengedepankan akhlak mulia dalam setiap aktivitas intelektualnya. Seperti diungkapkan Subaidi bahwa pendidikan Islam harus berorientasi nilai-nilai kemanusiaan yaitu mampu memahami realitas diri dan masyarakat sekitar serta mampu menciptakan perubahan sosial secara signifikan dalam kehidupan. Menghayati Islam secara komprehensif baik ilmu agama maupun umum adalah sebagai paradigma pendidikan Islam yang humanis. ${ }^{53}$

${ }^{49}$ Detri Karya, et al., Pendidikan Karakter di Universitas Islam Riau Melahirkan Pribadi Unggul (Pekanbaru: t.p., t.t.), h. 58.

${ }^{50}$ Ibid., h. 59-74.

${ }^{51}$ Ibid., h. 78.

${ }^{52}$ Ibid., h. 87.

${ }^{53}$ Subaidi, "Konsep Pendidikan Islam dengan Paradigma Humanis," dalam Tarbawi: Jurnal Pendidikan Islam, Vol. 11, No. 2, 2014, h. 26-49. 


\section{Kampus Hijau (Green Campus)}

Universitas Islam Riau memiliki prinsip bahwa alam adalah makhluk Tuhan dan sekaligus menjadi sahabat yang harus dijaga dan dilestarikan. Islam memang mengajarkan bahwa manusia adalah makhluk yang memiliki potensi untuk memakmurkan alam dengan memanfaatkannya. Memanfaatkan alam tidak harus merusak dengan cara-cara yang batil seperti membakar, menebang, mengeksploitasi secara berlebihan tanpa melakukan kajian akan dampak-dampak yang akan timbul kemudian.

Berpijak dari kesadaran UIR bahwa alam adalah bahagian dari anugerah Tuhan, maka UIR menjadikan moto kampusnya sebagai green campus. Pesan ini menjadi pertanda bahwa UIR sangat peduli terhadap lingkungan. Lingkungan tidak hanya dipandang sebagai ladang mengais rezeki, tetapi lingkungan juga sebagai sahabat yang akan memberikan kesejukan, kenyamanan, dan rasa aman. Atas prinsip inilah UIR mendesain kampusnya dengan menanam dan memelihara berbagai pohon. Untuk memelihara pohon dan tumbuhtumbuhan yang ada di area kampus, UIR mengangkat pegawai-pegawai profesional dan kreatif dan juga UIR telah menyediakan alat-alat operasional yang dapat digunakan setiap saat.

Eksistensi UIR sebagai perguruan tinggi Islam memang sudah tepat memilih langkah ini, mengingat daerah Riau termasuk daerah yang sering dilanda kabut asap akibat pembakaran yang dilakukan oleh orang-orang yang tidak bertanggung jawab. UIR sendiri selalu mengecam dan turut aktif dalam memutus mata rantai pembakaran hutan dan gambut di daerah Riau. Tindakan pembakaran liar terhadap hutan dan gambut ini memang tidak dapat ditolerir, sebab efeknya sangat nyata bagi kehidupan. Hal inilah yang dimaksud Allah SWT. dalam Q.S. al-Rûm/30: 41. Ayat ini telah mengingatkan manusia untuk memperlakukan alam dengan baik.

Allah SWT. memang menyediakan alam untuk dapat dimanfaatkan manusia, tetapi memanfatkan alam tidak berarti merusaknya, baik daratan maupun lautan. Daratan dan lautan harus dikelola dengan profesional. Di sinilah pentingnya melibatkan perguruan tinggi yang memliki prinsip menjunjung tinggi nilai-nilai untuk dapat dilakukan riset apakah layak atau tidak jika ingin memanfaatkan sumber daya alam. Jadi, UIR melalui konsep green campus telah berupaya untuk mengintegrasikan kurikulumnya dengan pola pembiasaan dalam menjaga alam sekitar. Namun untuk sampai kepada prinsip ini tentu tidak cukup dengan menanam pohon begitu saja tetapi harus menanamkan kesadaran bahwa alam adalah baharu. Prinsip dari sifat baharunya alam akan berdampak kepada adanya kemungkinan untuk berubah. Laju-lambatnya dan positif-negatifnya perubahan lingkungan sangat erat kaitannya dengan bagaimana manusia memperlakukan alam tersebut. Bahkan menyadari manusia sebagai makhluk baharu yang berpotensi untuk diubah (dididik) juga sangat membantu untuk menanamkan sikap menjaga alam dan lingkungan supaya tetap hijau dan memberi manfaat bagi kehidupan. Jika manusia telah memiliki kesadaran ini maka prestasi apapun yang diraih dalam mengelola alam 
dan lingkungan pasti selalu mengarah kepada pengagungan Allah SWT. ${ }^{54}$ Dengan kata lain, membina dan mengarahkan orang kepada nilai-nilai universal rabbaniyah akan melahirkan kemampuan menangkap berbagai sinyal spiritual, kalau tidak manusia akan terjebak dalam kehidupan pragmatisme dan hedonisme. ${ }^{55}$

\section{Penutup}

Berdasarkan kajian yang dilakukan, dapat ditarik kesimpulan bahwa Universitas Islam Riau sejak berdirinya tahun 1962 telah menjadikan Islam sebagai asasnya. Hal ini sesuai dengan visi dan misi Yayasan Lembaga Pendidikan Islam (YLPI) Riau. YLPI sendiri punya moto "Berbuat Baiklah Sebagaimana Allah Berbuat Baik Kepadamu”. Dalam visi, misi, dan tujuan UIR secara jelas diuraikan bahwa Universitas Islam Riau adalah lembaga pendidikan tinggi yang menjunjung tinggi nilai-nilai agama Islam. Penemuan, pengembangan, dan penyampaian ilmu pengetahuan, teknologi dan humaniora tidak dapat dipisahkan dengan ajaran Islam itu sendiri. Jadi ide dasar integrasi ilmu telah diletakkan oleh para pendiri Univeristas Islam Riau. Sebagai bentuk implementasi dari konsep integrasi ilmu di Universitas Islam Riau, para pengambil kebijakan telah berusaha untuk menyisipkan nilainilai rabbaniyah ke dalam setiap aspek yang ada. Misalnya turunan dari visi, misi, dan tujuan Universitas Islam Riau tersebut telah melahirkan berbagai program unggulan dimulai dari pemuatan kurikulum yang terintegrasi dengan Islam, malah mata kuliah ke-Islaman diatur dengan baik melalui Surat Keterangan Rektor dan menjadi pedoman bagi setiap dosen yang mengampu mata kuliah Pendidikan Agama Islam. Selain itu pembinaan ke-Islaman dosen, karyawan, pegawai, mahasiswa juga dilakukan dengan berbagai program yang diselenggarakan oleh unit-unit yang dibentuk oleh Universitas Islam Riau.

Pembinaan karakteristik keluarga besar Universitas Islam Riau juga tidak luput perhatian, sehingga digagaslah model Cerdas, Empati, Religius, Ikhlas, dan Amanah (CERIA) dan ini disosialisasikan secara intensif untuk menumbuhkan sikap agamis civitas akademika Universitas Islam Riau. Kemudian untuk meningkatkan kesadaran beragama civitas akademika Universitas Islam Riau juga mempromosikan moto green campus. Moto ini memberikan pesan bahwa insan akademis tidak hanya pintar secara intelektual, tidak hanya baik kepada sesama manusia, tetapi kepada lingkungan sekalipun manusia harus tetap memiliki sikap yang baik. Jadi, Universitas Islam Riau sejauh ini telah memiliki konstruksi integrasi ilmu pengetahuan, walaupun sifatnya masih pada tataran amaliah, sehingga ke depan Universitas Islam Riau mau tidak mau harus melakukan upaya sistematis dan berkesinambungan agar mampu melahirkan formulasi integrasi ilmu

\footnotetext{
${ }^{54}$ Musaddad Harahap dan Lina Mayasari Siregar, "Konsep Pendidikan Islam Dalam Membentuk Manusia Paripurna," dalam Jurnal Pendidikan Agama Islam Al-Thariqah, Vol. 2, No. 2, 2017, h. 148-163.

${ }^{55}$ Imam Hanafi, "Basis Epistemologi dalam Pendidikan Islam," dalam Jurnal Pendidikan Islam, Vol. 1. No. 1. 2012, h. 19-30.
} 
pengetahuan yang berciri khas untuk kemajuan Islam itu sendiri. Sebab, universitas ini sudah memilih Islam sebagai landasan operasionalnya.

\section{Pustaka Acuan}

Akbarizan. Integrasi Ilmu: Perbandingan antara UIN Suska Riau dan Universitas Ummu al-Qur'an Makkah. Pekanbaru: Suska Press, 2014.

Al Rasyidin dan Ja'far. Filsafat Ilmu dalam Tradisi Islam. Medan: Perdana Publishing, 2015.

Al Rasyidin. Falsafah Pendidikan Islami: Membangun Kerangka Ontologi, Epistimologi, dan Aksiologi Praktik Pendidikan. Bandung: Citapustaka Media Perintis, 2012.

Al-Ashfahani, al-Raghib. Al-Mufradat fi Gharib al-Qur'an, terj. Ahmad Zaini Dahlan, Jilid 1. Depok: Pustaka Khazanah Fawa'id, 2017.

Amin Abdullah, M. "Religion, Science and Culture: An Integrated, Interconnected Paradigm of Science," dalam Al-Jami'ah: Journal of Islamic Studies, Vol. 52, No. 1, 2014.

Amril, M. Epistemologi Integratif-Interkonektif Agama dan Sains. Jakarta: RajaGrafindo Persada, 2016.

Asyari, Suaidi. "Incorporating Islamism Into Secular Education System: An Attempt of Gradual Islamization of the State and Society by an Indonesian Tarbiyah Movement in Jambi," dalam Journal of Indonesian Islam, Vol. 11, No. 1, 2017.

Bakar, Osman. Tauhid dan Sains: Esai-Esai Tentang Sejarah dan Filsafat Sains Islam. Bandung: Pustaka Hidayah, 1995.

Fahmi, Muhammad. "Pendidikan Islam Perspektif Fazlur Rahman," dalam Jurnal Pendidikan Agama Islam (Journal of Islamic Education Studies), Vol. 2, No. 2, 2014.

Garadian, Endi Aulia. "Para Wali Nyentrik: Rekontekstualisasi Islamisasi di Tanah Jawa, Menantang Fundamentalisme Islam," dalam Studia Islamika, Vol. 26, No. 2, 2019.

Hanafi, Imam. "Basis Epistemologi Dalam Pendidikan Islam," dalam Jurnal Pendidikan Islam, Vol. 1. No. 1. 2012.

Hanafi, Muchlis Muhammad. "Integrasi Ilmu dalam Perspektif al-Qur'an," dalam Suhuf Jurnal Pengkajian al-Qur'an dan Budaya, Vol. 3, No. 2, 2010.

Harahap, Musaddad dan Lina Mayasari Siregar. "Konsep Pendidikan Islam Dalam Membentuk Manusia Paripurna," dalam Jurnal Pendidikan Agama Islam AlThariqah, Vol. 2, No. 2, 2017.

Humaidi. Paradigma Sains Integratifal-Farabi. Jakarta: Sadra Internasional Institute, 2015.

Karya, Detri. Buku Pedoman Akademik UIR Unggul dan Terkemuka di Asia Tenggara 2020. Pekanbaru: UIR, 2014.

Karya, Detri. Pendidikan Karakter di Universitas Islam Riau Melahirkan Pribadi Unggul. Pekanbaru: t.p., t.t. 
Keputusan Menteri Dalam Negeri No. Desember /I/44-25 pada tanggal 20 Januari 1959. Lembaga Dakwah Islam Kampus. "Latar Belakang Lembaga Dakwah Islam Kampus," dalam http://ldik.uir.ac.id/wb/pg/article/program/detail/1109/, 14 Oktober 2018.

Miftahuddin. "Integrasi Pengetahuan Umum dan Keislaman di Indonesia: Studi Integrasi Keilmuan di Universitas Islam Negeri di Indonesia," dalam Attarbiyah: Journal of Islamic Culture and Education, Vol. 1, No. 1, 2016.

Mollah, Moch. Kalam. "Konsep Interaksi Edukatif Dalam Pendidikan Islam Dalam Perspektif al-Qur'an," dalam Jurnal Pendidikan Agama Islam (Journal of Islamic Education Studies), Vol. 3, No. 2, 2015.

Mustaqim, Yunus. "Pengembangan Konsepsi Kurikulum Dalam Pendidikan Islam," dalam Edukasia: Jurnal Penelitian Pendidikan Islam, Vol. 9, No. 1, 2014.

Othman, Azam, et al. "Islamic Integrated Education System Model in the Malay Archipelago: Implications for Educational Leadership," dalam Intellectual Discourse, Vol. 25, No. $1,2017$.

Pemerintah Provinsi Riau. "Sejarah Terbentuknya Riau," dalam https://www.riau.go.id/ home/content/61/data-umum, 06 Agustus 2018.

Surat Keputusan Rektor Nomor 296/UIR/KPTS/2018 Tentang Tim Seleksi Mentor Bimbingan Baca al-Qur'an Universitas Islam Riau.

Surat Keputusan Rektor Universitas Islam Riau Nomor 1142/UIR/KPTS/2016 Tentang Penetapan Rencana Pembelajaran Semester Mata Kuliah Agama Islam Universitas Islam Riau, Pekanbaru, 21 Desember 2016.

Syahnan, Mhd. Hukum Islam dalam Bingkai Transdisipliner. Medan: Perdana Publishing, 2018.

Tuah, Abdul Hafiz Mat. "Pendekatan Falsafah Sains al-Qur'an Dalam Kurikulum Pendidikan Kebangsaan," dalam Jurnal Ushuluddin, Vol. 23, No. 2, 2017.

UIN Suska Riau. "Sejarah Singkat Universitas", dalam https://uin-suska.ac.id/profil/ sejarah-ringkas-universitas/, 06 Agustus 2018.

Undang-Undang Republik Indonesia Nomor 12 Tahun 2012 Tentang Pendidikan Tinggi.

Universitas Islam Riau. "Visi, Misi dan Tujuan UIR," dalam https://uir.ac.id/visi-misi, 14 Oktober 2018.

"Universitas Riau," dalam http://unri.ac.id/sejarah/, 04 Agustus 2018.

Wahab, Abdul. "Dualisme Pendidikan di Indonesia," dalam Lentera Pendidikan: Jurnal Ilmu Tarbiyah dan Keguruan, Vol. 16, No. 2, 2013.

Yahya, Amiruddin. "Dinamika Lembaga Pendidikan Tinggi Islam di Indonesia," dalam MIQOT: Jurnal Ilmu-ilmu Keislaman, Vol. 41, No. 1, 2017.

YLPI. Sejarah Singkat, Visi dan Misi Serta Keadaan YLPI Riau Saat Ini. Pekanbaru, YLPI, 2017. 